\title{
Management of Winery Wastewater by Re-using it for Crop Irrigation - A Review
}

\author{
C.L. Howell*, P.A. Myburgh \\ ARC Infruitec-Nietvoorbij (The Fruit, Vine and Wine Institute of the Agricultural Research Council), Private Bag X5026, 7599, \\ Stellenbosch, South Africa
}

Submitted for publication: July 2017

Accepted for publication: October 2017

Key words: Chemical oxygen demand, grapevines, potassium, water quality, wine

\begin{abstract}
In South Africa, grapes are an important crop in the Western and Northern Cape provinces. The wine industry makes a significant contribution to the economy in these regions. Wineries generate large volumes of poor quality wastewater, particularly during harvest. Information on actual amounts of water used by wineries is limited and appears to be inconsistent. Usually, most of the raw water entering wineries ends up as wastewater. Winery wastewater has high levels of chemical oxygen demand (COD) and contains high levels of $\mathrm{K}^{+}$and $\mathrm{Na}^{+}$. There is considerable variation in wastewater quality parameters between wineries, as well as a strong seasonal variation. In most cases, the wastewater is used for the irrigation of small, permanent-pasture grazing paddocks. The use of winery wastewater for vineyard irrigation could have many potential benefits for the wine industry. Irrigation with wastewater containing high levels of $\mathrm{K}^{+}$could be beneficial to soil fertility, although long-term application could have negative effects on soil chemical properties. In terms of South African guidelines, wineries must register their intended wastewater use with the Department of Water and Sanitation. The quantity of wastewater irrigated on a weekly basis has to be monitored and the wastewater quality has to be measured monthly. Weekly water balances should be drawn up with the assistance of a soil scientist. When selecting crops for irrigation with winery wastewater, soil characteristics and climatic conditions, as well as wastewater quality and quantity, should be considered. It is important to quantify soil chemical responses to the application of winery wastewater every three months.
\end{abstract}

\section{INTRODUCTION}

In South Africa, grapes are an important crop in regions such as the Western Cape province and the Lower Orange River region in the Northern Cape province. The wine industry makes a significant contribution to the economy in these regions. In 2014, there were 3314 primary wine grape growers (South African Wine Industry Information and Systems [SAWIS], 2015). Furthermore, the wine industry provides a large number of employment opportunities, particularly in the rural areas. In 2014, the vineyards planted for wine production in South Africa amounted to 99463 hectares, of which c. $93 \%$ were considered as producing, i.e. four years and older (SAWIS, 2015). The number of wineries that crush grapes almost doubled from 1991 to 2002 (Table 1). Since 2005, the number of wineries appeared to be more or less stable. During this period, the industry produced around one billion litres of grape-related products annually (Table 2).

Using raw water is an integral part of wine production processes. However, these processes generate wastewater of low quality that cannot be disposed of in natural systems. Winery wastewater can cause the salinisation and eutrophication of water resources, i.e. natural streams, rivers, dams, groundwater and wetlands (Van Schoor, 2005 and references therein; Laurenson et al., 2012). Furthermore, wastewaters can cause soil sodicity, salinity, contamination with a wide range of chemicals, waterlogging and anaerobiosis, as well as loss of soil structure and increased susceptibility to erosion. Where solid wastes are present, offensive odours may be generated and seepage may result in the contamination of soil and water resources, giving rise to the inhibition of vegetative performance (Van Schoor, 2005 and references therein).

\section{VOLUME OF WATER USED BY THE WINE INDUSTRY Water used for winemaking}

Information on the actual amounts of water used by wineries is limited and appears to be inconsistent. A survey carried out in South Africa, which included wineries that crush up to 22000 tonnes of grapes annually, showed that the volume of raw water increases significantly with the amount of grapes

*Corresponding author: E-mail address: howellc@arc.agric.za

Acknowledgments: This literature review paper forms part of Project K5/2561//4, funded by the Water Research Commission (WRC), Winetech and the Agricultural Research Council (ARC). 
crushed (Sheridan et al., 2005). Although the variability between wineries was high, the slope of the relationship indicated that approximately $2 \mathrm{~m}^{3}$ of water was required to crush one tonne of grapes. The Lutzville Vineyards' winery uses a measured average of $100000 \mathrm{~m}^{3}$ water to produce between 30 million and 40 million litres of wine annually (Kriel, 2008). Since this particular winery crushes approximately 47500 tonnes per year (G. Theron, personal communication), about $2.1 \mathrm{~m}^{3}$ of raw water is required to process one tonne of grapes. Although the amount of grapes crushed is substantially higher, the amount of water used by Lutzville Vineyards' winery agrees with the results of the survey carried out by Sheridan et al. (2005). According to Mosse et al. (2011), wineries in Australia generally require $3 \mathrm{~m}^{3}$ to $5 \mathrm{~m}^{3}$ of water to crush a tonne of grapes. The average annual grape production in South Africa was 1.33 million tonnes from 2010 until 2012 (SAWIS, 2013). If it is assumed that winemaking in South Africa requires approximately $2 \mathrm{~m}^{3}$ of water to process one tonne of grapes, it can be roughly estimated that the wine industry is currently using 2.66 million litres of raw water annually. It has been reported that $30 \%$ to $40 \%$ of the water used by wineries is used during the harvest period (Conradie, 2015).

\section{Volume of wastewater generated during winemaking}

Reports of the actual volumes of wastewater generated by wineries are also extremely limited. It is estimated that medium to large wineries generate more than $15000 \mathrm{~m}^{3}$ of wastewater annually, whereas small wineries generate less than $15000 \mathrm{~m}^{3}$ annually (Van Schoor, 2005 and references therein). Australian wineries generate about $5 \mathrm{~m}^{3}$ of wastewater per tonne of grapes crushed (Chapman et al., 1995). Crushing c. 50000 tonnes of grapes annually generates about $175000 \mathrm{~m}^{3}$ of wastewater at the Berri Estate Winery in the Riverland region of South Australia (Anonymous, 2010). Hence, their wastewater generation amounts to $c .3 .5 \mathrm{~m}^{3}$ per tonne of grapes. Most of the raw water entering wineries usually ends up as wastewater. It is estimated that $50 \%$, i.e. $50000 \mathrm{~m}^{3}$, of the raw water used by the Lutzville Vineyard Winery ends up as wastewater (Kriel, 2008). The other half of the water is presumably lost to evaporation under the warm, windy atmospheric conditions. This means that this particular winery generates about $1.1 \mathrm{~m}^{3}$ of wastewater per tonne of grapes crushed. In comparison, substantially lower volumes, viz. $0.359 \mathrm{~m}^{3}$ and $0.357 \mathrm{~m}^{3}$ of wastewater per tonne of grapes crushed, was generated in French cellars by offskin white winemaking and by rosé and thermo-vinification of red wines respectively (Bories \& Sire, 2010). An even lower value, of $0.262 \mathrm{~m}^{3}$ of wastewater generated per tonne of grapes crushed, was reported for the on-skin vinification of red wines (Bories \& Sire, 2010).

\section{ORIGIN OF WINERY WASTEWATER AND ASSOCIAT- ED POLLUTANTS}

\section{Sources of pollutants}

Wineries vary in size, operational procedures and management practices. They undertake similar, yet highly site-specific, processes. The variations result in the production of different qualities and quantities of wastewater (Van Schoor, 2005). Winemaking methods can have an impact on the quality of the wastewater generated (Bories \& Sire, 2010). In off-skin winemaking, wastewaters are produced that contain mainly sugars. On the other hand, in cellars where classical red winemaking methods are followed, wastewaters are generated that have high ethanol levels. The typical wine production process can be divided into various stages (Table 3). Medium to large wineries with year-round operations generate $c$. 50\% of their wastewater during the vintage period, whereas small

TABLE 1

Growth trends in the South African wine industry (SAWIS, 2015).

\begin{tabular}{lrrrrrrrr}
\hline \multirow{2}{*}{ Role player } & \multicolumn{8}{c}{ Number } \\
\cline { 2 - 8 } & $\mathbf{1 9 9 1}$ & $\mathbf{2 0 0 2}$ & $\mathbf{2 0 0 5}$ & $\mathbf{2 0 0 8}$ & $\mathbf{2 0 1 1}$ & $\mathbf{2 0 1 2}$ & $\mathbf{2 0 1 3}$ & $\mathbf{2 0 1 4}$ \\
\hline Wine cellars that crush grapes & 212 & 427 & 581 & 504 & 505 & 509 & 564 & 559 \\
Co-operatives & 70 & 66 & 65 & 58 & 52 & 50 & 50 & 49 \\
Wine-producing wholesalers & 6 & 11 & 21 & 23 & 25 & 23 & 21 & 25 \\
\hline
\end{tabular}

TABLE 2

Wine production trends in the South African wine industry (SAWIS, 2015).

\begin{tabular}{lrrrrrrrr}
\hline & \multicolumn{7}{c}{ Production (million litres) } \\
\cline { 2 - 8 } Product & $\mathbf{2 0 0 5}$ & $\mathbf{2 0 0 8}$ & $\mathbf{2 0 0 9}$ & $\mathbf{2 0 1 0}$ & $\mathbf{2 0 1 1}$ & $\mathbf{2 0 1 2}$ & $\mathbf{2 0 1 3}$ & $\mathbf{2 0 1 4}$ \\
\hline Wine & 628.5 & 780.2 & 739.0 & 779.8 & 831.2 & 870.9 & 915.5 & 958.8 \\
Rebate & 82.9 & 88.0 & 75.8 & 39.6 & 34.2 & 62.3 & 42.0 & 53.6 \\
Juice & 64.6 & 66.9 & 55.0 & 52.1 & 40.2 & 40.1 & 58.7 & 35.1 \\
Distilling wine & 146.4 & 157.9 & 152.2 & 113.3 & 107.2 & 123.6 & 140.7 & 133.6 \\
\hline Total & 1043.5 & 1093.0 & 1022.0 & 984.8 & 1012.8 & 1096.9 & 1156.9 & 1181.1 \\
\hline
\end{tabular}


TABLE 3

Typical stages of winery activities and their role in wastewater generation (Van Schoor, 2005 and references therein).

Stage Activities

Duration (weeks)

1. Pre-harvest

Bottling takes place and tanks are washed out with sodium or potassium hydroxide. Other equipment is also washed to prepare for the harvest period.

1 to 4

2. Early harvest Wastewater generation increases drastically during this period and reaches $40 \%$ of the maximum weekly rate measured at peak. White wine production dominates harvest activities.

3. Peak harvest Wastewater generation and harvest activities reach their peak.

3 to 14

4. Late harvest

Wastewater generation decreases to $40 \%$ of the maximum (peak) weekly flow and red wine production dominates harvest activities. Distillation of ethanol may take place.

5. Post-harvest Pre-fermentation activities come to an end and maximum usage of hydroxide occurs.

6. None harvest

Wastewater volume is at its minimum (less than $30 \%$ of the peak weekly flow). Wastewater quality depends on daily activities.

wineries may generate up to $80 \%$ of their wastewater during harvest (Van Schoor, 2005). The major form of wastewater from wineries is water used for cleaning processes (Van Schoor, 2005). Primary winemaking processes related to winery wastewater generation and their associated contribution to wastewater quantity and quality, as well as possible effects on legal wastewater quality parameters, are summarised in Table 4 . The primary water quality parameters are chemical oxygen demand (COD), electrical conductivity (EC), sodium adsorption ratio (SAR) and $\mathrm{pH}$.

\section{Quality of wastewater generated in wineries}

In contrast to the volumes of wastewater produced, there are many reports on the quality thereof, particularly in terms of COD or biological oxygen demand (BOD) (Chapman et al., 1995; Ryder, 1995; Deans, 2003; Jeison et al., 2003; Sheridan et al., 2005; Baker \& Hinze, 2007; Kriel, 2008; Matthews, 2008; Arienzo et al., 2009; Mulidzi et al., 2009b; Conradie et al., 2014; Howell et al., 2014a; Buelow et al., $2015 \mathrm{~b}$ ). The BOD is estimated as $66 \%$ of the COD (Van Schoor, 2005). Winery wastewaters also contain high levels of $\mathrm{K}^{+}$and $\mathrm{Na}^{+}$(Laurenson et al., 2012; Conradie et al., 2014). Although various parameters may be used to evaluate winery wastewater, $\mathrm{COD}, \mathrm{pH}, \mathrm{SAR}, \mathrm{EC}, \mathrm{Cl}^{-}, \mathrm{K}^{+}$and $\mathrm{Na}^{+}$ are considered to be important. A survey was carried out in 2000 to evaluate the winery wastewater generated by the South African industry in terms of these variables (Mulidzi et al., 2009b). The results of this survey show that there is considerable variation in wastewater quality parameters between wineries, but there is also a strong seasonal variation at most wineries. A similar seasonal trend was reported for winery wastewater in Australia (Arienzo et al., 2009). These trends were confirmed where the effluents of two wineries were monitored frequently (Sheridan et al., 2011). Considering the legal requirements for irrigation water quality in South Africa (Table 5), the results of the survey confirmed that the majority of South African wineries are not able to irrigate crops beneficially as part of the general authorisation relating to wastewater, unless the water is first subjected to an effective form of pre-treatment, or unless there is a relaxation in the general authorisations.

Different winemaking processes also affect the composition of winery wastewater. In the case of off-skin winemaking, sugars are the main component of the organic load in the effluent water, whereas classical winemaking methods generate wastewaters containing high levels of ethers and ethanol (Bories \& Sire, 2010). However, it is also possible that spikes of extremely low quality can be caused by process interruptions. Power failures, fires, floods, storms, over- or under-loading of wastewater treatment systems, temporary unavailability of wastewater holding dam capacity and the absence of trained operators may cause process interruptions (Campos et al., 2000; Van Schoor, 2005; Baker \& Hinze, 2007).

\section{MANAGEMENT OF WINERY WASTEWATER Wastewater treatment}

Wastewater is usually collected in one or more sumps at the wineries. The first step in the treatment of winery wastewater is usually to remove the solids, such as grape pips, skins and stems, by passing the water through a screen filter. This is a simple, but effective step and helps to prevent other treatment machinery from getting clogged with solids (Mosse et al., 2011). The wastewater is normally acidic and the $\mathrm{pH}$ can be less than 3. Lime is therefore added to the water in order to increase the $\mathrm{pH}$ to the legal or crop requirement (Van Schoor, 2005). The water is then pumped to sedimentation or maturation ponds to allow settling of the remaining solids. Depending on the quality of the wastewater at this stage, the water can be used to irrigate selected crops, such as kikuyu grass, in specific soils. A further step could be to circulate and aerate the wastewater in dams using an aeration pump system. If these steps are managed correctly, the treatment of the wastewater can be fairly successful, particularly in reducing the COD levels (Tables 6 and 7, and Fig. 1).

Up-flow anaerobic sludge blanket (UASB) technology can also be used to treat winery wastewater (Matthews, 2008). This technology relies on anaerobic digestion, a biological process in which organic matter is converted to methane and carbon dioxide in the absence of air. The process involves a synergistic relationship between four different groups 
TABLE 4

Major processes related to winery wastewater generation and their associated contribution to wastewater quantity and quality as well as possible effects on legal wastewater quality parameters (Van Schoor, 2005).

\begin{tabular}{|c|c|c|c|}
\hline Winery operation & $\begin{array}{l}\text { Contribution to total } \\
\text { wastewater quantity }\end{array}$ & $\begin{array}{l}\text { Contribution to } \\
\text { wastewater quality }\end{array}$ & $\begin{array}{l}\text { Effect on legal wastewater } \\
\text { quality parameters }\end{array}$ \\
\hline \multicolumn{4}{|l|}{ Cleaning water } \\
\hline $\begin{array}{l}\text { Alkali washing (removal of } \\
\text { K-bitartrate) and neutralisation }\end{array}$ & Up to $33 \%$ & $\begin{array}{l}\text { Increase in } \mathrm{Na}^{+}, \mathrm{K}^{+}, \\
\mathrm{COD}^{(1)} \text { and } \mathrm{pH} \\
\text { Decrease in } \mathrm{pH}\end{array}$ & $\begin{array}{l}\text { Increase in } \mathrm{EC}^{(2)}, \mathrm{SAR}^{(3)} \text {, } \\
\mathrm{COD} \\
\text { Variation in } \mathrm{pH}\end{array}$ \\
\hline $\begin{array}{l}\text { Rinse water (tanks, floors, transfer } \\
\text { lines, bottles, barrels, etc.) }\end{array}$ & Up to $43 \%$ & $\begin{array}{l}\text { Increase in } \mathrm{Na}^{+}, \mathrm{P}^{-} \mathrm{Cl}^{-} \\
\text {COD }\end{array}$ & $\begin{array}{l}\text { Increase in } \mathrm{EC}, \mathrm{SAR}, \mathrm{COD} \\
\text { Variation in } \mathrm{pH}\end{array}$ \\
\hline \multicolumn{4}{|l|}{ Process water } \\
\hline Filtration with filter aid & Up to $15 \%$ & Various contaminants & Increase COD and EC \\
\hline Acidification and stabilisation of wine & Up to $3 \%$ & $\mathrm{H}_{2} \mathrm{SO}_{4}$ or $\mathrm{NaCl}$ & $\begin{array}{l}\text { Increase COD and EC } \\
\text { Decrease in } \mathrm{pH}\end{array}$ \\
\hline Cooling tower waste & Up to $6 \%$ & Various salts & Increase COD and EC \\
\hline \multicolumn{4}{|l|}{ Other sources } \\
\hline Laboratory practices & Up to $5 \%$ to $10 \%$ & $\begin{array}{l}\text { Various salts, variation } \\
\text { in } \mathrm{pH}, \text { etc. }\end{array}$ & Increase $\mathrm{COD}$ and $\mathrm{EC}$ \\
\hline
\end{tabular}

\footnotetext{
(1) Chemical oxygen demand

(2) Electrical conductivity

(3) Sodium adsorption ratio
}

TABLE 5

General Authorisations for legislated limits of chemical oxygen demand (COD), faecal coliforms, $\mathrm{pH}$, electrical conductivity (EC) and sodium adsorption ratio (SAR) for irrigation using wastewater in South Africa (Department of Water Affairs, 2013).

\begin{tabular}{|c|c|c|c|}
\hline \multirow[b]{2}{*}{ Parameter } & \multicolumn{3}{|c|}{ Maximum irrigation volume allowed (m³/day) } \\
\hline & $<\mathbf{5 0}$ & $<\mathbf{5 0 0}$ & $<2000$ \\
\hline $\mathrm{COD}^{(1)}(\mathrm{mg} / \mathrm{L})$ & 5000 & 400 & 75 \\
\hline Faecal coliforms (per $100 \mathrm{~mL}$ ) & 1000000 & 100000 & 1000 \\
\hline $\mathrm{pH}$ & $6-9$ & $6-9$ & $5.5-9.5$ \\
\hline $\mathrm{EC}^{(2)}(\mathrm{mS} / \mathrm{m})$ & 200 & 200 & $70-150$ \\
\hline $\mathrm{SAR}^{(3)}$ & $<5$ & $<5$ & Other criteria apply \\
\hline
\end{tabular}

(1) Chemical oxygen demand

(2) Electrical conductivity

(3) Sodium adsorption ratio

of bacteria, namely hydrolytic, fermentative-acidogenic, acetogenic and methanogenic. The bacteria cluster into granules, which settle out to form a dense bed of sludge that is retained in the system. This is a distinct advantage over aerobic systems, which produce masses of surplus sludge that must be disposed of. The methane is produced as a waste gas, which can be recovered as an energy source (Mosse et al., 2011). However, disadvantages are that nutrient removal is not feasible in anaerobic systems and trained staff are needed to operate UASB systems. Anaerobic digestion is often limited by the presence of refractory and toxic compounds in the wastewater, but ozone helps counter this effect. Pre-ozonation enhances the biodegradability of organic matter by converting these compounds into simpler molecules. Post-ozonation may be used as a "polishing" step. In addition, installation costs are relatively high (Mosse et al., 2011).

Worldwide, most UASB plants have operational volumes of 100000 litres to 10 million litres (Matthews, 2008). Only a few operate on less than 50000 litres. A winery near Franschhoek operates a relatively small, fully automatic UASB system that can treat 25000 litres per day. This particular wastewater treatment plant reduces the COD to $c .250 \mathrm{mg} / \mathrm{L}$ throughout the year. It was also shown that UASB technology can be used for the successful treatment of wastewater generated in the production of Chilean pisco, an aged drink distilled from grapes (Jeison et al., 2003). Expanded granular sludge bed (EGSB) technology was also tested in this study, but it was more difficult to operate and required higher capital 
TABLE 6

Mean winery wastewater quality during the crushing season and in aerated storage ponds in California's North Coast region (Ryder, 1995).

\begin{tabular}{lcc}
\hline Parameter & Crushing season & Reclaimed water \\
\hline $\mathrm{COD}^{(1)}(\mathrm{mg} / \mathrm{L})$ & 3780 & 15 \\
$\mathrm{pH}$ & 4.1 & 7.7 \\
$\mathrm{~N}(\mathrm{mg} / \mathrm{L})$ & 20 & 5 \\
$\mathrm{P}(\mathrm{mg} / \mathrm{L})$ & 10 & 2 \\
Dissolved solids $(\mathrm{mg} / \mathrm{L})$ & 800 & 500 \\
\hline
\end{tabular}

(1) Chemical oxygen demand

TABLE 7

Variation of chemical oxygen demand (COD) and total suspended solids (TSS) in raw and treated winery effluent (Baker \& Hinze, 2007).

\begin{tabular}{lcccc}
\hline & \multicolumn{2}{c}{$\mathbf{C O D}^{(\mathbf{1})}(\mathbf{m g} / \mathbf{L})$} & \multicolumn{2}{c}{ TSS $^{(2)}(\mathbf{m g} / \mathbf{L})$} \\
\cline { 2 - 5 } Sampling date & Wastewater & Final effluent & Wastewater & Final effluent \\
\hline $2005-11-18$ & 9091 & 16 & 1700 & 92 \\
$2005-12-19$ & 2727 & 28 & 265 & 66 \\
$2006-02-13$ & 3788 & 8 & 280 & 16 \\
$2006-03-23$ & 6621 & 788 & 940 & 1080 \\
$2006-04-28$ & 644 & 72 & 319 & 683 \\
$2006-06-08$ & 5788 & 64 & 245 & 460 \\
$2007-01-18$ & 4848 & 14 & 400 & 53 \\
$2007-03-28$ & 6712 & 379 & 1040 & 617
\end{tabular}

(1) Chemical oxygen demand adjusted from biological oxygen demand (BOD), where BOD $=66 \%$ of COD

(2) Total soluble solids

investment, as well as higher operational costs, compared to the UASB technology.

\section{Disposal or utilisation of winery wastewater \\ Return to natural resources}

In terms of the general authorisations published in Government Notice No. 665 (Department of Water Affairs, 2013) in terms of section 39 of the National Water Act (1998), untreated wastewater from wine cellars would rarely, if ever, qualify for discharge into natural water resources (Van Schoor, 2005). Given the quality of the treated water, most wastewaters would still not be suitable for discharge into natural water resources. Consequently, this practice is not really considered as a disposal option.

\section{Disposal ponds}

Some wineries pump the treated wastewater into ponds or storage dams. If the water is not re-used for irrigation, it evaporates or seeps into deeper soil layers if the ponds or dams are unlined (Mulidzi et al., 2009a). Multi-stage facultative aerobic ponds have been used successfully for some 30 years for the treatment and storage of winery wastewater in California (Ryder, 1995). These ponds are lined to prevent seepage of the water into underground water streams and are aerated sufficiently to prevent the generation of objectionable odours.

\section{Irrigation with winery wastewater}

In South Africa, more than $93 \%$ of wine cellars dispose of their effluent by means of land application (Van Schoor, 2005). The majority of cellars currently dispose of effluent by irrigation as the primary disposal option. Land application systems are ideally suited for the treatment of the organic $\mathrm{C}$ contained in winery effluents because the water in the soil system transports the organic contaminants to the aerobic microbial populations. However, it is important that waterlogging should be avoided. Consequently, it is essential to allow sufficient time between irrigations for the soil to become aerobic (Chapman et al., 1995).

\section{Crops irrigated with winery wastewater}

In most cases, the wastewater is used for the irrigation of small, permanent pasture grazing paddocks close to the wineries. The pastures mainly consist of kikuyu grass, but fescue grass can also be irrigated with winery wastewater (Arienzo et al., 2009). There are also cases in Australia 


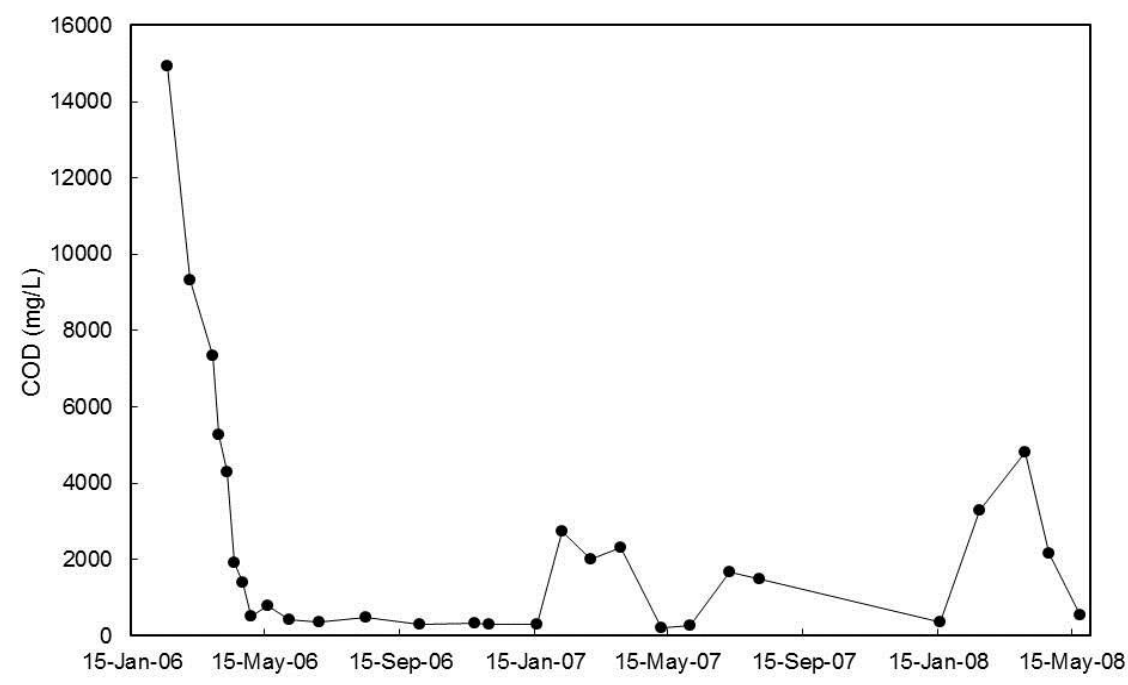

FIGURE 1

Seasonal variation in level of chemical oxygen demand (COD) in treated winery wastewater following aeration of the water, which commenced in January 2006 (data supplied courtesy of the Botha winery).

where treelots, e.g. Eucalyptus camaldulensis, are irrigated with winery wastewater (Chapman et al., 1995; Deans, 2003; Anonymous, 2010). Research results have also shown that lemon nursery trees could successfully be irrigated with wastewater generated by a pisco distillery after the water had been treated using UASB technology (Jeison et al., 2003). The pisco distillery wastewater was also disposed of in a eucalyptus tree lot on a commercial scale.

Winery wastewater stored in lined and aerated ponds is used for vineyard irrigation during the rain-free spring and summer in California (Ryder, 1995). At a winery in the Clare Valley in Australia, treated wastewater, of which the COD contents are presented in Table 7, is recycled into the raw irrigation water to be used for the irrigation of grapevines (Baker \& Hinze, 2007). In this particular case, the treated wastewater constitutes only $10 \%$ of the annual irrigated volume. The actual wastewater applied was less than $10 \mathrm{~mm}$. Although some vineyards have been irrigated for long periods using winery wastewater, the effect thereof on the soils and grapevines have not been reported. Despite there being extensive literature available regarding the irrigation of grapevines with saline water (Walker et al., 1997; Stevens et al., 1999; Ben-Asher et al., 2006; Stevens et al., 2011), there is little information on using winery wastewater diluted to a pre-determined COD level on grapevine growth, yield and juice responses. The irrigation of grapevines using winery wastewater diluted up to $3000 \mathrm{mg} / \mathrm{L} \mathrm{COD} \mathrm{did} \mathrm{not}$ affect grapevine water status, vegetative growth, production or evapotranspiration, irrespective of the level of dilution (Howell et al., 2014b). The results showed that the irrigation of grapevines using diluted winery wastewater did not have detrimental effects on juice characteristics with regard to ripeness parameters and ion content. Wine sensorial characteristics were not affected by irrigation using diluted winery wastewater (Howell et al., 2014c). The grapevines did not respond to COD level per se. This indicates that sufficient aeration occurred between irrigations, which allowed the breakdown of organic C. Although the salinity and sodicity levels in the diluted winery wastewater were below the thresholds at which a reduction in growth and yield are expected for grapevines, they should be monitored frequently. The low salinity and sodicity levels in the diluted winery wastewater could be a further explanation for why the grapevines did not respond negatively to the wastewater irrigation. Where "simulated" winery wastewater was used for vineyard irrigation, there were no substantial differences in ripeness parameters, yield and vegetative growth after one year (Mosse et al., 2013). Although high $\mathrm{K}^{+}$concentrations in artificial wastewater promoted the accumulation of harvest petiole $\mathrm{K}^{+}$, petiole $\mathrm{Ca}^{2+}$ was reduced substantially. When artificial wastewater contained organic matter together with high $\mathrm{K}^{+}$levels, petiole $\mathrm{Ca}^{2+}$ was not reduced to the same extent. The use of $\mathrm{Na}^{+}$-based artificial wastewater increased petiole $\mathrm{Na}^{+}$levels substantially. In a glasshouse study, in which winery wastewater was applied either undiluted, or diluted in different ratios to potted Shiraz grapevines, petiole $\mathrm{K}^{+}$contents were below the recommended levels, irrespective of dilution level (Kumar et al., 2014). In addition to the different levels of winery wastewater dilution, there were also treatments in which solutions of different $\mathrm{K}^{+}$and $\mathrm{Na}^{+}$ nutrient loads were used to irrigate grapevines. Increasing $\mathrm{K}^{+}$concentrations increased petiole $\mathrm{K}^{+}$(Kumar et al., 2014). The authors concluded that solutions should not be used to study winery wastewater effects. On a field scale, in two paired field trials in which grapevines were irrigated with either mains water or winery wastewater, there was no difference in the sensorial evaluation of the wines (Kumar et al., 2014). Furthermore, where grapevines were irrigated with winery wastewater, wine $\mathrm{Na}^{+}$levels were still below $100 \mathrm{mg} / \mathrm{L}$, whereas wine $\mathrm{K}^{+}$ranged from $1220 \mathrm{mg} / \mathrm{L}$ to $1400 \mathrm{mg} / \mathrm{L}$ and was within industry norms for red wines in Australia (Kumar et al., 2014).

A range of leaf analyses was carried out in representative areas of a eucalyptus plantation in which the Berri Estates 
Winery disposed of its wastewater (Anonymous, 2010). The relatively low nutrient levels in the winery wastewater were reflected in declining, but still acceptable, levels of $\mathrm{N}$, $\mathrm{P}$ and $\mathrm{K}^{+}$in the leaves. However, it was concluded that some nutrient addition might be necessary during the lifespan of the trees. During the first weeks after planting, the leaves of eucalyptus saplings that were irrigated with wastewater treated in a UASB reactor showed symptoms of $\mathrm{Na}^{+}$toxicity (Jeison et al., 2003). The lemon trees used in the experiments showed similar symptoms. The problem was caused by the $\mathrm{NaOH}$ required for $\mathrm{pH}$ control in the UASB reactor. Approximately $2 \mathrm{~g} / \mathrm{L}$ of $\mathrm{NaOH}$ had been applied during the first weeks after reactor start up. However, after a few weeks the biogas production provided a significant level of alkalinity from $\mathrm{CO}_{2}$ dissolution. Consequently, $\mathrm{NaOH}$ application was reduced to less than $20 \%$ of its original level. The eucalyptus saplings recovered without any permanent damage. Unfortunately, the $\mathrm{Na}^{+}$concentrations in the treated wastewater were not reported. There are also no other reports on the effects of irrigation with winery wastewater on the performance of most of the different species mentioned above.

Recently, research has shown that potted fodder beet grown during summer in sandy soil collected from the field trial at Rawsonville absorbed $38 \%$ of the $\mathrm{Na}^{+}$applied via $\mathrm{Na}^{+}$-enriched irrigation water (Myburgh \& Howell, 2014). The concentration of $\mathrm{Na}^{+}$applied was equal to that of the $\mathrm{Na}^{+}$concentration in the irrigation water of the $3000 \mathrm{mg} / \mathrm{L}$ COD treatment in the field trial. Furthermore, the fodder beet reduced exchangeable soil $\mathrm{K}^{+}\left(\mathrm{K}_{\text {ex }}^{+}\right)$by $50 \%$, indicating that it could also absorb $\mathrm{K}^{+}$applied via winery wastewater.

Where Pennisetum glaucum L. cv. Babala (pearl millet) was cultivated as an interception crop to intercept salts applied via diluted winery wastewater for vineyard irrigation, the use of winery wastewater improved the dry matter production (DMP) of the specific crop (Fourie et al., 2015). It was also clear that the pearl millet intercepted substantial amounts of $\mathrm{K}^{+}$applied via the diluted winery wastewater. In contrast, the pearl millet did not absorb substantial amounts of $\mathrm{Na}^{+}$applied in the same manner. In winter, a cover crop of oats was also cultivated. It was reported that the oats cover crop also absorbed substantial amounts of $\mathrm{K}^{+}$applied via the diluted winery wastewater.

\section{Irrigation systems used to dispose of winery wastewater}

High-volume sprinklers are commonly used to apply irrigation to grazing paddocks. Full-surface flood irrigation was used to dispose of winery wastewater onto fescue grass (Arienzo et al., 2009) and a eucalyptus plantation (Anonymous, 2010). It must be noted that, in the latter case, diatomaceous earth solids entered the pipeline used to transport the winery wastewater to the plantation during the grape harvesting period. This required annual flushing and/ or pigging to avoid blockages. Unfortunately, most other reports on the disposal of winery wastewater by means of irrigation did not mention the systems used to irrigate the different species. Since vineyards in Australia are almost invariably drip irrigated, it can be assumed that the winery in the Clare Valley in Australia disposed of the treated wastewater by means of a drip irrigation system (Baker
\& Hinze, 2007). Aboveground as well as subsurface drip irrigation was used in a field experiment in Israel to irrigate grapevines with water from sewerage waste stabilisation ponds (Campos et al., 2000). The rationale for using drip irrigation, and particularly subsurface drip irrigation, was to minimise the risk of disease contamination by preventing direct contact between the wastewater and the edible part of the crop.

\section{Effects of winery wastewater on soil conditions}

Soil chemical status: Irrigation with wastewaters containing high levels of $\mathrm{K}^{+}$, such as winery wastewater, could be beneficial to overall soil fertility, although long-term application could have negative effects on soil chemical properties (Smiles \& Smith, 2004; Kumar et al., 2009; Laurenson et al., 2011; Mosse et al., 2011). Land application of wastewaters can increase the levels of soluble and exchangeable forms of potassium $\left(\mathrm{K}^{+} \& \mathrm{~K}^{+}{ }_{\mathrm{ex}}\right)$ more rapidly than with conventional inorganic fertilisers (Arienzo et al., 2009). Furthermore, most of the $\mathrm{K}^{+}$in wastewater is immediately available. The effects of high $\mathrm{K}^{+}$concentrations on soil properties have not been extensively researched and are still unclear (Kumar et al., 2009; Mosse et al., 2011; Laurenson et al., 2012). In addition, the fate of $\mathrm{K}^{+}$in soils and on grapevines irrigated with winery wastewater has received limited attention (Laurenson et al., 2012). A further advantage of using winery wastewater as a source of $\mathrm{K}^{+}$over the use of conventional fertiliser is that it could be an efficient recycling practice in areas where the soil has low $\mathrm{K}^{+}$. It is highly likely that high soil $\mathrm{K}^{+}$could lead to an increase in $\mathrm{K}^{+}$uptake by grapevines. This could have negative consequences for grapevine responses, such as musts with high $\mathrm{pH}$ and malate concentrations and poor colour (Jackson \& Lombard, 1993; Mpelasoka et al., 2003; Kodur, 2011). However, the effect of soil $\mathrm{K}^{+}$on $\mathrm{K}^{+}$concentrations in the must is often negligible, unless excessive amounts are applied (Jackson \& Lombard, 1993). In addition to $\mathrm{Na}^{+}$and $\mathrm{K}^{+}$ions, winery wastewater can also contain $\mathrm{Ca}^{2+}$ and $\mathrm{Mg}^{2+}$ ions (Mosse et al., 2011). Neither of the latter ions are harmful to soil structure, and they can ameliorate the impacts of $\mathrm{Na}^{+}$via their role in reducing the SAR. A further matter of potential concern is $\mathrm{Na}^{+}$and $\mathrm{Mg}^{2+}$ accumulation in surface soils and the subsequent loss of $\mathrm{Ca}^{2+}$ (Laurenson, 2010).

A survey was carried out in South Africa to assess the soil chemical status where winery wastewater had been disposed over prolonged periods (Mulidzi et al., 2009a). Control soil samples were collected close to the area of land where the wastewater was disposed. Unfortunately, there was no history about the volumes of water or the quality of the wastewater that had been applied to the disposal sites. By comparing the disposal site to the control samples, however, it was shown that the winery wastewater almost invariably induced negative effects, irrespective of soil type (Mulidzi et al., 2009a). Furthermore, it was concluded that (i) in general, effluent disposal is poorly planned and managed, and disposal sites rarely seem to have been properly selected because their soil properties are inappropriate for effluent disposal. In particular, deep sandy soils are unsuitable for disposal by ponding, mainly because of their high infiltration rates, high permeability and low water storage capacity; and 
(ii) many disposal sites are too limited in area to permit the large volumes of effluent to be absorbed without surface runoff. This problem invariably persists despite the presence of Kikuyu swards and sandy subsoil (Mulidzi et al., 2009a). Irrigation using undiluted winery wastewater increased soil $\mathrm{K}^{+}$to a depth of $90 \mathrm{~cm}$ (Mulidzi et al., 2009a). A literature search revealed that the effect of irrigation with winery wastewater on soil P is not well documented. With respect to $\mathrm{P}$, Mulidzi et al. (2009a) reported that land application of undiluted winery wastewater increased soil $\mathrm{P}$, but that the $\mathrm{P}$ in the different soil horizons fluctuated throughout the season.

More recently, Mulidzi (2016) investigated the effect of the application of undiluted winery wastewater by wineries on the soil chemical dynamics in two different soils that were irrigated with undiluted winery wastewater for three years. Over-irrigation with the winery wastewater in combination with winter rainfall caused large amounts of cations, particularly $\mathrm{K}^{+}$and $\mathrm{Na}^{+}$, to leach beyond a soil depth of $90 \mathrm{~cm}$. The leached elements will most likely end up in natural water resources over time. It was reported that irrigation with undiluted winery wastewater did not have a pronounced effect on soil $\mathrm{pH}_{(\mathrm{KCl})}$. This was probably due to the decomposition of organic matter and the fact that the applied salts, as well as dissolved organic or mineral acids, leached beyond a depth of $90 \mathrm{~cm}$.

In a pot study in which four soils, varying in parent material and clay content, were irrigated with either winery wastewater diluted to $3000 \mathrm{mg} / \mathrm{L}$ or municipal water for four 'simulated' seasons, the rate of $\mathrm{K}^{+}$increase in the shalederived soil that contained $20 \%$ clay was higher than in the soils containing 13\% clay or less (Mulidzi et al., 2015). This indicates that heavier soils will increase the risk of high soil $\mathrm{K}^{+}$levels. Excessive soil $\mathrm{K}^{+}$could lead to excessive uptake by the grapevine, increasing juice and wine $\mathrm{pH}$, with negative effects on wine colour and microbial stability (Mpelasoka et al., 2003; Kodur, 2011). It was also reported that the risk of $\mathrm{Na}^{+}$accumulation increased linearly with clay content (Mulidzi et al., 2015). Irrigation with diluted winery wastewater increased soil $\mathrm{pH}_{(\mathrm{KCl})}$ due to the addition of organic/bicarbonate salts to the soil. The $\mathrm{pH}_{(\mathrm{KCl})}$ in the shale and granite-derived soils was increased to such an extent that it was moved into the optimum range for $\mathrm{P}$ availability. Although $\mathrm{pH}_{(\mathrm{KCl})}$ in the aeolic sand was initially above the optimum range, relatively high $\mathrm{Na}^{+}$levels also caused available $\mathrm{P}$ to increase as the $\mathrm{pH}_{(\mathrm{KCl})}$ increased (Mulidzi et al., 2016). However, there was a reduction in available $P$ in the case of the alluvial sand, as the soil $\mathrm{pH}_{(\mathrm{KCl})}$ increased beyond the optimum range (Mulidzi et al., 2016). This indicates that irrigation with diluted winery wastewater may only enhance $\mathrm{P}$ absorption if the $\mathrm{pH}$ shift is towards the optimum (Mulidzi et al., 2016). It should be noted that the results reported were for a worst-case scenario, i.e. in the absence of rainfall or crops (Mulidzi et al., 2015).

There was no change in soil $\mathrm{pH}$ where winery wastewater was used for the irrigation of soil with a clay content of $50 \%$ to $60 \%$ (Quale et al., 2010). In contrast, the soil $\mathrm{pH}_{(\mathrm{H} 2 \mathrm{O})}$ of a silty clay loam soil that received solid and liquid winery waste for 30 years tended to increase compared to soil to which no waste was applied (Mosse et al., 2012). In two case studies in which pastures and a vineyard were irrigated with winery wastewater, the soil $\mathrm{pH}$ also increased (Kumar et al., 2014). However, comparing the results with a historical dataset of soil chemical properties, it seems that irrigation with winery wastewater actually caused a decrease in soil $\mathrm{pH}$. In a laboratory study in which mains water, municipal wastewater or winery wastewater was used for the irrigation of a sand, loamy sand and sandy loam, there was an increase in soil $\mathrm{pH}_{(1.5)}$ (Laurenson, 2010). However, it should be borne in mind that the winery wastewater $\mathrm{pH}$ in that particular study was 8.5 . There have also been conflicting reports of either an increase or decrease in soil $\mathrm{pH}$ (Laurenson et al., 2012 and references in). It was suggested that these soil $\mathrm{pH}$ changes can be related to the characteristics of the wastewater. If wastewaters contain high concentrations of bicarbonate, application to soils will increase $\mathrm{pH}$, whereas acidic wastewaters could reduce soil $\mathrm{pH}$. In a laboratory study, soil $\mathrm{EC}_{(1: 5)}$ was not affected by irrigation with either mains water, municipal wastewater or winery wastewater, regardless of soil type (Laurenson, 2010). Similarly, in another laboratory study, the soil EC of a loam and loamy sandy soil did not respond to winery wastewater irrigation (Kumar et al., 2006). However, soil EC was higher where woodlots were irrigated with winery wastewater compared to a control (Kumar et al., 2009).

In pastures irrigated with undiluted winery wastewater for over 100 years, the levels of total organic carbon (TOC), $\mathrm{N}, \mathrm{K}^{+}, \mathrm{Na}^{+}, \mathrm{Mg}^{2+}$ and $\mathrm{Ca}^{2+}$ increased relative to the controls (Kumar et al., 2006). Although soil $\mathrm{K}^{+}, \mathrm{Na}^{+}, \mathrm{Mg}^{2+}$ and $\mathrm{Ca}^{2+}$ of pastures irrigated with undiluted winery wastewater for 15 to 20 years increased, these increases were not as substantial as in pastures that had been irrigated for 100 years (Kumar et al., 2006). However, there were no differences with regard to $\mathrm{Ca}^{2+}$ and $\mathrm{Mg}^{2+}$ in the soil. Irrigation using winery wastewater containing high levels of organic $\mathrm{C}$ increased total soil organic $\mathrm{C}$ content (Kumar et al., 2009). In addition, soil $\mathrm{K}^{+}$, as well as salinity and sodicity levels, was higher in wastewater-treated plots compared to control plots, particularly woodlot and pasture sites at certain wineries. Soil $\mathrm{K}^{+}$and $\mathrm{Na}^{+}$levels were also higher in vineyard soils irrigated with winery wastewater compared to a control vineyard that was irrigated with river water (Kumar et al., 2006). Kumar et al. (2006) also reported that the higher organic $\mathrm{C}$ content of winery wastewater resulted in an increased total organic $\mathrm{C}$ content in soils irrigated using such wastewater. According to Kumar et al. (2014), both soil $\mathrm{K}^{+}$and SAR increased throughout the soil profile where winery wastewater was used for irrigation. In a laboratory study, irrigation with winery wastewater increased soil $\mathrm{Na}^{+}$ and $\mathrm{K}^{+}$in a loamy sand, a loam and a clayey soil (Kumar et al., 2006). It should be noted that these soils were collected from areas where winery wastewater was being used for the irrigation of woodlots, pastures or vineyards.

Where winery wastewater was applied to a silty clay loam soil for 30 years, soil $\mathrm{K}^{+}, \mathrm{Na}^{+}, \mathrm{Ca}^{2+}, \mathrm{Mg}^{2+}$ and $\mathrm{B}^{3+}$ were substantially higher compared to soil where no winery wastewater was applied (Mosse et al., 2012). Furthermore, soil that had been irrigated with winery wastewater for 30 years showed a decrease in soil $\mathrm{pH}$ with depth. The increased concentrations of the cations was attributed to their higher 
levels in the wastewater.

It was reported that $\mathrm{K}^{+}$in the surface layer increased where winery wastewater was used for the irrigation of soil with a clay content of $50 \%$ to $60 \%$ (Quale et al., 2010). However, there were no changes in sub-soil $\mathrm{K}^{+}$due to the slow mobility of $\mathrm{K}^{+}$in the soil. There were no changes in soil $\mathrm{Ca}^{2+}$, but soil $\mathrm{Mg}^{2+}$ tended to decrease.

Although there is an extensive literature available regarding the effect of irrigation with wastewaters of various origins on soil chemical properties, there is little information regarding the re-use of winery wastewater diluted to predetermined levels of COD for any crop. It should be noted that most of the studies investigating the effects of winery wastewater on soil properties entailed responses being compared to a control to which no winery wastewater was applied or were conducted in pots in laboratories, often with artificial "winery wastewater". In a field trial where a sandy alluvial soil was irrigated with winery wastewater diluted up to $3000 \mathrm{mg} / \mathrm{L}$ there were no clear trends in soil $\mathrm{pH}_{(\mathrm{KCl}) \text {, }}$ $\mathrm{EC}_{\mathrm{e}}$ or acidity, but $\mathrm{EC}_{\mathrm{e}}$ was substantially higher after the seasonal wastewater irrigations compared to at bud break (Howell \& Myburgh, 2014a). This was probably due to the higher salt content in the diluted wastewaters. Soil K (Bray II) after wastewater application consistently increased with a decrease in the dilution of the wastewater and, after four years, only the lowest level of dilution, i.e. $3000 \mathrm{mg} / \mathrm{L} \mathrm{COD,}$ maintained baseline $\mathrm{K}^{+}$levels. The increase in soil Bray II-K was linearly related to the additional amounts of $\mathrm{K}^{+}$applied via the diluted winery wastewater. Increases in soil $\mathrm{K}^{+}$could have a negative impact on wine colour stability should the $\mathrm{K}^{+}$be taken up by the grapevine in sufficient quantities, particularly if soil $\mathrm{K}^{+}$accumulates to such an extent that it is luxuriously absorbed by the grapevines. Soil $\mathrm{Ca}^{2+}$ and $\mathrm{Mg}^{2+}$ did not show any consistent responses to the different levels of wastewater augmentation because there were no substantial differences in the amounts of these elements applied via the irrigation water. Soil $\mathrm{Na}^{+}$also increased linearly as the level of wastewater dilution decreased, particularly in the topsoil. Changes in cation ratios due to the accumulation of $\mathrm{K}^{+}$and $\mathrm{Na}^{+}$, with no subsequent increase in $\mathrm{Ca}^{2+}$ and $\mathrm{Mg}^{2+}$, could be detrimental in terms of soil physical properties. In this particular study, it was reported that there were no consistent trends with regard to soil organic $\mathrm{C}$ that could be related to the level of dilution of the winery wastewater. This means that the organic $\mathrm{C}$ content in the diluted wastewaters was still too low to have had a positive effect on soil fertility. It is also possible that organic material in the diluted wastewaters, which could have led to an accumulation of organic soil C, decomposed when the soil was aerated between irrigations. It should be noted that the results represent a specific in-field situation, i.e. in the presence of rainfall and crops. Although irrigation with winery wastewater had almost no other effects under the prevailing conditions, it was reported that element accumulation, particularly with respect to $\mathrm{K}^{+}$and $\mathrm{Na}^{+}$, might be more prominent in heavier soils or in regions with low winter rainfall. In addition, natural water resources could be polluted with leached elements such as $\mathrm{K}^{+}$and $\mathrm{Na}^{+}$during the winter.

In the only field study of its kind investigating the irrigation of an established vineyard using artificial winery wastewater, grapevines were either irrigated with lake water or with artificial wastewaters containing high $\mathrm{K}^{+}$, high $\mathrm{K}^{+}$plus wine, low $\mathrm{K}^{+}$, and $\mathrm{Na}^{+}$(Mosse et al., 2013). All treatments caused an increase in soil $\mathrm{K}^{+}$and $\mathrm{Na}^{+}$. The accumulation of $\mathrm{K}^{+}$was restricted to the $0 \mathrm{~cm}$ to $20 \mathrm{~cm}$ soil layer, with the exception of the treatment in which wine was added to the irrigation water. The addition of wine enhanced $\mathrm{K}^{+}$transport into the subsoil. Elevated $\mathrm{Na}^{+}$levels were found in the $0 \mathrm{~cm}$ to $20 \mathrm{~cm}$ and $20 \mathrm{~cm}$ to $40 \mathrm{~cm}$ soil layers. Therefore, the presence of wine, i.e. organic material, facilitated the transport of the $\mathrm{K}^{+}$within the profile.

Soil physical status: Unfortunately, no references could be found in the literature dealing with the effect(s) of irrigation using winery wastewater on in-field soil physical properties. Although the effect of irrigation using winery wastewater on soil chemical properties is well documented, its effect on soil physical properties is largely unknown, particularly when used for vineyard irrigation (Buelow et al., 2015a). This could be due to the fact that changes in soil physical properties are difficult to quantify because they tend to occur only over the long term, and that soil physical properties are greatly variable (Hawke \& Summers, 2006). Furthermore, most of the studies were conducted in laboratories using artificial solutions.

Soil chemical properties can be altered by wastewater irrigation (Vogeler, 2009; Lado \& Ben-Hur, 2010) and this could influence soil structure (Sparling et al., 2006) and hydraulic properties (Mathan, 1994; Sort \& Alcaniz, 1999; Tarchitzky et al., 1999; Al-Haddabi et al., 2004; Coppola et al., 2004; Viviani \& Iovino, 2004; Hawke \& Summers, 2006; Gonçalves et al., 2007; Arienzo et al., 2009; Vogeler, 2009). Dissolved and suspended solids, both organic and inorganic, may induce soil clogging through physical, chemical and biological processes (Viviani \& Iovino, 2004). The degradation of soil hydraulic properties as a result of physical clogging of the surface layer of soil is one of the expected risks involved in wastewater reuse for irrigation (Viviani \& Iovino, 2004). The effects of wastewater irrigation are closely related to both wastewater and soil properties. An accumulation of monovalent cations, such as $\mathrm{K}^{+}$and $\mathrm{Na}^{+}$, which are generally associated with winery wastewater, can have negative effects on soil structure (Laurenson et al., 2012).

Soil column studies show that the reduction in saturated hydraulic conductivity was only restricted to the $0 \mathrm{~cm}$ to 2 $\mathrm{cm}$ depth layer, and the lower part of the column was not affected by wastewater application (Viviani \& Iovino, 2004).

Irrigation using olive mill wastewaters increased soil hydrophobicity and reduced drainable porosity because of increasing organic matter content (Mahmoud et al., 2010). Furthermore, soil hydraulic conductivity was reduced compared to a control site. After 15 years of application of such wastewater, the highest infiltration rate was observed because of the presence of large and deep shrinkage cracks. According to Barbera et al. (2013), irrigation using olive mill wastewaters can have a temporary positive effect on the soil. However, in clay soils, salt accumulation could lead to the disintegration of the soil structure. Subsequently, the hydraulic conductivity would decrease. Regarding the use 
of wastewater generated by oil production, research has shown that the use of such water created a sodicity problem, which had negative effects on soil physical properties such as infiltration rate, saturated hydraulic conductivity and pore size distribution (Al-Haddabi et al., 2004).

After four years of irrigation using secondary-treated municipal wastewater, the saturated and near saturated hydraulic conductivity of a soil decreased from $567 \mathrm{~mm} / \mathrm{h}$ and $40 \mathrm{~mm} / \mathrm{h}$ to $56 \mathrm{~mm} / \mathrm{h}$ and $3 \mathrm{~mm} / \mathrm{h}$, respectively (Sparling et al., 2006). In a study on a sewage farm to investigate the effects of long-term irrigation using sewage effluent on soil physical properties, bulk density was significantly lower compared to that of soil that was irrigated with well water. Furthermore, the longer the irrigation with sewage water took place, the lower the bulk density became (Mathan, 1994), and hydraulic conductivity subsequently increased. In a study to evaluate the long-term effect of wastewater application on soil physical properties, it was also found that this practice increased the organic matter content and reduced bulk density. In addition to this, long-term wastewater irrigation resulted in a higher aggregate stability and saturated hydraulic conductivity (Vogeler, 2009). In a column study, leaching a loamy and a clay soil with treated sewage effluent reduced saturated hydraulic conductivity (Lado \& Ben-Hur, 2009 and references therein) due to the plugging of pores with suspended solids. However, the saturated hydraulic conductivity of a sandy soil was not affected because of its large pore size. In a non-calcareous, sandy soil, higher sodicity enhanced seal formation, reduced infiltration and increased runoff. However, there were no effects of the effluent on runoff of a calcareous soil under similar conditions. According to Tarchouna et al. (2010), irrigation using wastewater from a sludge treatment plant reduced both the saturated and unsaturated hydraulic conductivity of a very sandy soil, but it was still high enough to allow water percolation.

The negative effects of high $\mathrm{Na}^{+}$levels in irrigation water on the hydraulic properties of soils are well known. According to Levy and Van der Watt (1990), increasing the amount of $\mathrm{K}^{+}$resulted in a decrease in the hydraulic conductivity and infiltration rate of soils. There is a broad spectrum of possible effects of $\mathrm{K}^{+}$on infiltration, ranging from being similar to $\mathrm{Na}^{+}$to being similar to $\mathrm{Ca}^{2+}$ (Arienzo et al., 2009). Furthermore, it was concluded that, relative to exchangeable $\mathrm{Ca}^{2+}$ and $\mathrm{Na}^{+}, \mathrm{K}^{+}$had an intermediate effect on soil hydraulic properties. Since winery wastewater can contain high $\mathrm{Na}^{+}$and/or $\mathrm{K}^{+}$concentrations, the effect of SAR and the potassium adsorption ratio (PAR) on the soil hydraulic conductivity at a wastewater disposal site was investigated in a laboratory study (Arienzo et al., 2009). The results showed that the soil hydraulic conductivity was considerably reduced when the SAR or the PAR exceeded 20. These negative effects occurred even when the electrolyte concentrations in the soil were relatively high, i.e. $>40 \mathrm{meq} / \mathrm{L}$. It was also shown that the negative effect of $\mathrm{Na}^{+}$was more pronounced compared to $\mathrm{K}^{+}$at the same electrolyte concentration.

The results of a laboratory study investigating the effect of SAR and PAR on soil hydraulic conductivity showed that the hydraulic conductivity was considerably reduced when the SAR or the PAR exceeded 20 (Arienzo et al.,
2009; 2012). In another study, Laurenson et al. (2012) used a combination of solutions with known SAR and PAR to investigate the binding of $\mathrm{Na}^{+}$and $\mathrm{K}^{+}$, and concluded that exchangeable sodium percentage (ESP) corresponding to a given SAR was increasingly lowered at higher $\mathrm{K}^{+}$ concentrations. Subsequently, if SAR in wastewater remains similar during the vintage, reductions in ESP may occur because of increasing $\mathrm{K}^{+}$and exchangeable potassium percentage (EPP). Changes in soil structure will therefore be less pronounced compared to wastewaters with comparable monovalent concentrations of only $\mathrm{Na}^{+}$. In the case of winery wastewater, replacing $\mathrm{Na}^{+}$-based cleaners with $\mathrm{K}^{+}$-based cleaners can contribute towards decreasing clay dispersion risks. Due to the high $\mathrm{K}^{+}$content in winery wastewater, the substitution of $\mathrm{K}^{+}$-based cleaning agents with $\mathrm{Na}^{+}$-based ones has been proposed (Arienzo et al., 2009). Using $\mathrm{Na}^{+}-$ based cleaning agents might reduce the $\mathrm{K}^{+}$, but in the long run increased $\mathrm{Na}^{+}$levels in the soil will probably cause more structural damage than $\mathrm{K}^{+}$. In addition, $\mathrm{Na}^{+}$could reach toxic levels in soils. On the other hand, $\mathrm{K}^{+}$accumulation in the soil could be reduced through uptake and removal by crops grown on winery wastewater disposal sites. Furthermore, it should be borne in mind that the cost of potassium hydroxide is substantially higher than that of $\mathrm{NaOH}$ (Mosse et al., 2011).

In the first study of its kind in which wastewater was diluted to irrigate four different soils in a field vineyard setup, near-saturation hydraulic conductivity $(\mathrm{K})$ of the shale-derived soil, as well as of the alluvial and aeolian sands, decreased substantially with a decrease in the level of dilution of winery wastewater after three years (Howell \& Myburgh, 2014b). It should be noted that the soils received no river water irrigation, which could have influenced the effect of the wastewater on near-saturation K. In spite of this, the results indicate that severe reductions in near-saturation $\mathrm{K}$ will occur in the long run if diluted winery wastewater is used for irrigation on these soils. Furthermore, the reduction in near-saturation $\mathrm{K}$ might be more pronounced if undiluted winery wastewater is used for irrigation of crops. Using three soils of contrasting mineralogy packed in soil columns, it was found that soil mineralogy and $\mathrm{Na}^{+}$and $\mathrm{K}^{+}$concentrations in solution were key factors influencing the soil hydraulic conductivity (Buelow et al., 2015a).

AVAILABLE MANAGEMENT GUIDELINES AS WELL AS EXISTING STANDARDS FOR AUTHORISATION OF USE OF AUGMENTED WINERY WASTEWATER FOR IRRIGATION OF VINEYARDS

\section{South Africa}

According to Van Schoor (2005), where winery wastewater is used for the irrigation of land, the intended water use must be registered with the Department of Water and Sanitation before irrigation can commence. Where granted, the guidelines stipulated in the General Authorisation (Table 5) must be adhered to. In terms of South African guidelines, it should be noted that irrigation may only take place above the 100 -year floodline. In addition, irrigation with wastewater may only take place $100 \mathrm{~m}$ or more from the edge of a water resource. No contamination of ground or surface water may take place. It is also necessary that wineries measure 
the quantity of wastewater irrigated on a weekly basis. In addition to this, wineries must measure the quality of the wastewater every month. It is recommended that overirrigation, waterlogging and damage to the soil must be prevented at all times. It should be noted that the purpose of wastewater irrigation should not only be the disposal of winery wastewater, but that there should be a beneficial use of water to irrigate crops (Van Schoor, 2005). In terms of South African guidelines for wineries, weekly water balances should be drawn up with the assistance of a soil scientist, and the accuracy of these calculations should be checked by continuous monitoring of the soil water. When selecting crops for irrigation with winery wastewater, soil characteristics and climatic conditions, as well as wastewater quality and quantity, should be considered (Van Schoor, 2005). It is important to collect soil samples from wastewaterirrigated soils at three depths at a minimum of five locations per hectare every three months. In addition, samples must be collected from a control area where no irrigation has taken place. All the soil samples must be analysed for $\mathrm{pH}, \mathrm{EC}, \mathrm{N}$, $\mathrm{P}, \mathrm{Ca}^{2+}, \mathrm{Mg}^{2+}, \mathrm{K}^{+}, \mathrm{Na}^{+}, \mathrm{Fe}^{2+}, \mathrm{Mn}^{2+}, \mathrm{Cu}^{2+}, \mathrm{Zn}^{2+}, \mathrm{B}^{3+}, \mathrm{Cl}^{-}, \mathrm{S}$ and ESP. If there are any indications of soil degradation, the area should be rehabilitated and another area or disposal method must be identified.

\section{Australia}

According to Day et al. (2011), the main focus in Australia is to (i) know the wastes; (ii) assess the treatment options; (iii) know the environment and end-use options; (iv) develop a holistic business case and (v) establish a duty of care on people. In South Australia, the principal legislation that addresses pollution is the Environment Protection Act, of which Section 25 imposes a general environmental duty on anyone who undertakes an activity that pollutes, or has the potential to pollute, to take all reasonable and practicable measures to prevent or minimise environmental harm. The management of winery waste is legislated under the South Australian Environment Protection Authority (EPA) Guidelines for Wineries and Distilleries (South Australian EPA, 2004). Facilities within the Mt Lofty Ranges Water Protection Area (Day et al., 2011) that process more than 50 tonnes of grapes or grape products per year must have an EPA license, and all licensed wineries and distilleries must develop and implement an environmental monitoring programme and submit the data collected to the EPA annually. According to this legislation, where winery wastewater is irrigated at rates greater than $100 \mathrm{~mm}$ per annum, routine soil testing is required to prove that the use of winery wastewater for irrigation did not negatively affect soil properties, in particular the soils' hydraulic properties. In the EPA Guidelines for Wineries and Distilleries, emphasis is placed on producing and managing winery wastewater of a given quality that is fit for the intended purpose, rather than general classifications.

As the quantity and types of wastes produced by wineries vary due to waste management practices and the activities undertaken, wineries must review and amend their monitoring programmes regularly to allow for changes in production methods and scale. The environmental monitoring programme submitted to the EPA must include (i) a schematic diagram to show the inputs and outputs of the winery; (ii) clear and concise descriptions of the processes being undertaken at the winery; and (iii) details of annual processing inputs and outputs.

Wineries must develop procedures to sample and monitor water coming into the winery (influent water), wastewater, soil, groundwater and other receiving environments (South Australian EPA, 2004). Analyses of all water samples must be undertaken by specific, accredited laboratories. The monitoring programme must be approved by the EPA before it is implemented. In addition, data obtained from the monitoring programme must be forwarded to the EPA, where it will be used to establish industry benchmarks and inform the public. As part of the quality management system, the EPA also requires that the monitoring activity and resulting data are verified by an independent, qualified professional. According to the guidelines, the influent water of the winery must be analysed annually for $\mathrm{pH}, \mathrm{EC}, \mathrm{Ca}^{2+}, \mathrm{Mg}^{2+}$ and $\mathrm{Na}^{+}$, and the SAR must be calculated. Optional analyses of the influent water include BOD, $\mathrm{N}, \mathrm{K}^{+}$and $\mathrm{Cl}^{-}$.

Wastewater flow volumes must be measured at a single location with properly calibrated flow meters, after wastewater has been collected and treated and before it is disposed or re-used. The flow measurements must also be synchronised with wastewater quality measurements to determine hydraulic and chemical loads. A record of winery wastewater volume must be provided annually to the EPA. According to the guidelines, sampling of the winery wastewater must reflect wastewater quality during the various production periods and must be performed at a suitable location before it is disposed of to land or re-used for irrigation. The number of samples required per production period depends on the wastewater produced per year. Winery wastewater must be analysed annually for BOD, $\mathrm{pH}, \mathrm{EC}$, $\mathrm{N}, \mathrm{P}, \mathrm{Ca}^{2+}, \mathrm{Mg}^{2+}, \mathrm{K}^{+}, \mathrm{Na}^{+}$and $\mathrm{Cl}^{-}$, and the water SAR must be calculated. Optional analyses of the winery wastewater include $\mathrm{COD}, \mathrm{TOC}, \mathrm{SO}_{4}^{2-}, \mathrm{CO}_{3}^{2-}$ and $\mathrm{HCO}_{3}$.

In South Australia, the EPA requires that the rate of wastewater application to land must be regulated according to four different criteria, namely (i) the dominant soil type in irrigated sites; (ii) the concentration of organic C, nutrients and salts in the wastewater; (iii) an analysis of organic $\mathrm{C}$, nutrient and salt balance to determine the potential effects on crop growth and long-term salt loadings; and (iv) the sensitivity of the area.

Wineries that irrigate with wastewater at a rate of $100 \mathrm{~mm}$ per year must include annual soil chemistry monitoring in their programmes. To minimise percolation to groundwater, wastewater must be applied at a rate equal to that at which it is removed by the crops. Daily water requirements can be estimated from a water balance. Soil water monitoring before and after wastewater application is an important tool, and records should be kept and made available to the EPA for inspection when required. It is also recommended that wineries seek the assistance of irrigation specialists to determine the system that best suits the needs of the site. According to the guidelines, soil monitoring must only be undertaken by qualified professionals, and monitoring locations must be properly marked to enable samples to be collected at locations adjacent to previous sampling points 
for comparison. Two samples of each dominant soil type must be taken in September or October at $0 \mathrm{~cm}$ to $20 \mathrm{~cm}$, $20 \mathrm{~cm}$ to $60 \mathrm{~cm}$ and below $60 \mathrm{~cm}$, and should be analysed for $\mathrm{pH}, \mathrm{N}, \mathrm{P}, \mathrm{K}^{+}, \mathrm{TOC}$ and water-soluble $\mathrm{EC}_{\mathrm{e}}, \mathrm{Ca}^{2+}, \mathrm{Mg}^{2+}$ and $\mathrm{Na}^{+}$, and the SAR must be calculated. A reference site is also required.

In addition to the soil samples, wineries that irrigate at $100 \mathrm{~mm}$ per year must monitor groundwater at the irrigation site if there is a groundwater aquafer less than $15 \mathrm{~m}$ below the surface. As in the case of the soil samples, sampling must only be undertaken by qualified professionals. The groundwater samples must be analysed for $\mathrm{pH}, \mathrm{EC}$, nitrate $\mathrm{N}$, ammonia $\mathrm{N}$ and TOC.

In terms of vegetation health, it is recommended that the health of plants irrigated with winery wastewater should be monitored visually. It is also recommended that wineries have a complaint register for complaints. It should be noted that most complaints relate to odour and noise.

\section{New Zealand}

According to Laurenson and Houlsbrooke (2012), it is important to prevent the harmful effects of applying winery wastes to land on aquatic environments and soil and plant health. The major concern regarding winery wastes is nutrients, high BOD and salts. However, concentrations of heavy metals and other contaminants are low and pose a limited environmental risk. In New Zealand, the Resources Management Act aims to promote the sustainable management of natural and physical resources and to provide the basis upon which regional policy statements, policies and district plans are prepared. Although the Act does not clearly address the management of waste, it does require that adverse effects associated with its disposal are avoided, mitigated or remedied. Therefore, wineries have to dispose of their wastewater in a sustainable manner that does not contaminate drinking water sources or result in off-site pollution.

It is recommended that a record be kept of the amount of wastewater produced (Laurenson \& Houlsbrooke, 2012), and that wastewater be sampled during the vintage to determine the appropriate loading rates for the land. It is recommended that the upper limit of the cation ratio of structural stability (CROSS) in winery wastewater should be 20 when the EC of the winery wastewater is $1.5 \mathrm{dS} / \mathrm{m}$.

Before winery wastewater is applied to the land, the soil depth, infiltration rate and maximum water deficit should be determined to identify irrigation management units (IMU). The quantity of wastewater applied to a specific area on a certain date should be recorded. In New Zealand, the code of practice for winery waste management recommends a BOD loading of no greater than $120 \mathrm{~kg} \mathrm{BOD} /$ ha/day. A high BOD in winery wastewater can reduce soil oxygen, particularly when the soil is saturated with large amounts of wastewater. However, the ability of soils to assimilate wastewater is rapid and anaerobic conditions are not persistent, particularly if winery wastewater is applied at rates suitable to the nutrient demand, and when there is a suitable soil water deficit.

Soil samples should be collected every one to two years to identify imbalances in soil fertility and/or the buildup of salts, and a nutrient budget should be drawn up for areas that are irrigated with winery wastewater (Laurenson $\&$ Houlsbrooke, 2012). For a land treatment system to be sustainable, it must be efficient in retaining waste constituents in both the soil and plants. The longer the wastewater remains in the root zone, the greater the time for the soil to physically filter out constituents, thereby diminishing potential contaminants and nutrients. In order to prevent the loss of nutrients in run off and drainage, the volume of winery wastewater applied by land application should be less than the total volume of water required by the soil. Therefore, a basic knowledge is required of the soil to which winery wastewater is being applied. Where sites contain more than one soil type, the hydraulic loadings should be adjusted for each soil. Where this is not possible, it is recommended that wastewater applications should be made for the most limiting soil. In New Zealand, it is recommended that the AgResearch Soil Risk Framework for effluent adopts IMU based on drainage classes.

Guidelines from all over the world state that no contamination of ground or surface water should occur during winery wastewater irrigation (Laurenson \& Houlsbrooke, 2012). This requires the consideration of both the depth and rate of application for each IMU. The application rate of winery wastewater has a strong influence on nutrient treatment efficiency when applied to soils that have a high degree of preferential flow or drainage limitations, or that are located on sloping land. Different soils have different infiltration rates and abilities to absorb and drain water. Winery wastewater application rates should be matched to the soils' ability to absorb the water. It should also be borne in mind that lower application rates increase the likelihood of retaining the applied nutrients in the root zone, decrease the likelihood of preferential flow, and allow a greater volume of applied wastewater to move through the smaller soil pores.

Ideally, wineries in New Zealand that also irrigate more than $100 \mathrm{~mm}$ of winery wastewater per year should monitor groundwater if it is less than $15 \mathrm{~m}$ below the surface, and surface water bodies if they are less than $50 \mathrm{~m}$ from the wastewater application site (Laurenson \& Houlsbrooke, 2012). Soil processes responsible for the attenuation and amelioration of waste constituents occur mostly within the active root zone. Hydraulic loading depths that allow for a longer contact time between the soil and waste constituents in the root zone will maximise nutrient assimilation.

In New Zealand, the permissible loading of $\mathrm{N}$ is restricted to 150 to $200 \mathrm{~kg} \mathrm{~N}$ per ha (Laurenson \& Houlsbrooke, 2012). In some soils, cracking, root and worm channels and large macro-pores may promote preferential flow that minimises the interaction between the soil and the winery wastewater, thereby limiting plant uptake. If the application of winery wastewater exceeds the water-holding capacity of the soil, or if the soil is wet, a large volume of the applied winery wastewater will flow preferentially through the macro-pores. By increasing the application frequency, the applied depth and nutrient loading rate in a single event can be reduced, thereby extending the retention time of winery wastewater in the root zone and improving plant nutrient-use efficiency by better matching demand. According to the authors, further knowledge of site-specific conditions, including the assessment of soil characteristics, mineralisation rates, 
climate and the agronomic needs of the crop, is still required. Furthermore, it is critical to know how much nutrient is directly available to the crop and how much will be removed by the crop. In the case of winery wastewater, the supply of large quantities of $\mathrm{K}^{+}$via winery wastewater could affect the nutrient balances and the mineral composition of the crop.

During winery wastewater irrigation, odour can be a problem and, in this regard, the frequency, intensity, duration and offensiveness of the odour are key factors. Generally, odours can be avoided by preventing anaerobic conditions in the winery wastewater during storage and irrigation, maintaining adequate separation distances to neighbouring properties, and by irrigating downwind at night.

\section{California}

Wastewater quality standards were proposed for the irrigation of vineyards using treated winery wastewater stored in aerated ponds in California (Ryder, 1995). The maximum COD, faecal coliforms, $\mathrm{pH}, \mathrm{EC}$ and SAR standards, given in Table 8, are more or less comparable to the legislated limits for irrigation with wastewater in South Africa, i.e. if less than $2000 \mathrm{~m}^{3}$ is irrigated per day (Table 5).

\section{CONCLUSIONS}

Wineries generate large volumes of poor quality wastewater, particularly during harvest. The use of winery wastewater for vineyard irrigation could have many potential benefits for the wine industry. Since water is becoming increasingly scarce, the use of winery wastewater as an alternative source of irrigation water for vineyards could reduce the pressure on water resources. However, there is no available information to guide legislators regarding what specific quality of winery wastewater could be permitted for application in vineyard irrigation under a specific set of conditions to minimise

TABLE 8

Proposed reclaimed effluent water quality standards for vineyard re-use (Ryder, 1995).

\begin{tabular}{|c|c|c|}
\hline Parameter & Optimum value & Maximum values \\
\hline $\mathrm{pH}$ & $6.5-8.4$ & $6.0-9.0$ \\
\hline $\mathrm{EC}^{(1)}(\mathrm{dS} / \mathrm{m})$ & $<0.75$ & $<1.50$ \\
\hline $\operatorname{TDS}^{(2)}(\mathrm{mg} / \mathrm{L})$ & $<500$ & $<1000$ \\
\hline Alkalinity $\left(\mathrm{mg} / \mathrm{L} \mathrm{CaCO}_{3}\right)$ & $<150$ & $<250$ \\
\hline Hardness $\left(\mathrm{mg} / \mathrm{L} \mathrm{CaCO}_{3}\right)$ & $<250$ & $<400$ \\
\hline $\mathrm{Ca}(\mathrm{mg} / \mathrm{L})$ & $<60$ & $<100$ \\
\hline $\operatorname{Mg}(\mathrm{mg} / \mathrm{L})$ & $<25$ & $<50$ \\
\hline $\mathrm{Na}(\mathrm{mg} / \mathrm{L})$ & $<65$ & $<100$ \\
\hline $\mathrm{K}(\mathrm{mg} / \mathrm{L})$ & $<5$ & $<10$ \\
\hline $\mathrm{Fe}(\mathrm{mg} / \mathrm{L})$ & $<5$ & $<5$ \\
\hline $\mathrm{Mn}(\mathrm{mg} / \mathrm{L})$ & $<0.2$ & $<0.5$ \\
\hline $\mathrm{Cu}(\mathrm{mg} / \mathrm{L})$ & $<0.01$ & $<0.05$ \\
\hline $\mathrm{Zn}(\mathrm{mg} / \mathrm{L})$ & $<2$ & $<5$ \\
\hline Bicarbonate (mg/L) & $<200$ & $<300$ \\
\hline Carbonate (mg/L) & $<5$ & $<10$ \\
\hline Chloride (mg/L) & $<70$ & $<120$ \\
\hline Sulphate (mg/L) & $<150$ & $<250$ \\
\hline $\mathrm{N}(\mathrm{mg} / \mathrm{L})$ & $<5$ & $<10$ \\
\hline $\mathrm{P}(\mathrm{mg} / \mathrm{L})$ & $<5$ & $<10$ \\
\hline $\mathrm{B}(\mathrm{mg} / \mathrm{L})$ & $<0.5$ & $<1$ \\
\hline $\mathrm{SAR}^{(3)}$ & $<6$ & $<9$ \\
\hline $\mathrm{COD}^{(4)}(\mathrm{mg} / \mathrm{L})$ & $<60$ & $<100$ \\
\hline Coliforms $\left(\mathrm{MPN}^{(5)} / 100 \mathrm{~mL}\right)$ & $<23$ & $<230$ \\
\hline
\end{tabular}

(1) Electrical conductivity

(2) Total dissolved solids

(3) Sodium adsorption ratio

(4) Chemical oxygen demand adjusted from biological oxygen demand (BOD), where BOD $=66 \%$ of COD

(5) Most probable number 
the effects on the soil and on grapevine responses. Most of the information generated with regard to wastewater has been collected in laboratory studies with either municipal wastewater or simulated wastewater. Consequently, there is a need for further studies in actual vineyards, in which winery wastewater is applied to vineyards over a longer term. In terms of South African guidelines, wineries need to register their intended wastewater use with the Department of Water and Sanitation. They need to monitor the quantity of wastewater irrigated on a weekly basis. In addition to this, the quality of winery wastewater needs to be measured monthly. Weekly water balances should be drawn up with the assistance of a soil scientist. In the selection of a crop to irrigate with winery wastewater, soil characteristics and climatic conditions, as well as wastewater quality and quantity, should be considered. It is important to quantify soil chemical responses to the application of winery wastewater every three months. Most importantly, South African guidelines state that, if there are any indications of soil degradation, the area should be rehabilitated and another area for wastewater irrigation must be identified.

\section{LITERATURE CITED}

Al-Haddabi, M., Ahmed, M., Kacimov, A., Rahman, S. \& Al-Rawahy, S., 2004. Impact of treated wastewater from oil extraction process on soil physical properties. Commun. Soil Sci. Plan. 35, 751-758.

Anonymous, 2010. Winery wastewater re-use to irrigate redgum plantations - Berri Estates [Online]: http://infohouse.p2ric.org/ref/04/03314/.

Arienzo, M., Christen, E.W., Quayle, W. \& Kumar, A., 2012. A review of the fate of potassium in the soil-plant system after land application of wastewaters. J. Hazard. Mater. 164, 415-422.

Arienzo, M., Quale, W.C., Christen, E. \& Jayawardane, N., 2009. Irrigating with winery wastewater? Developing soil stability thresholds and managing total cations. Aust. N.Z. Grapegrow. Winem. October, 86-88.

Baker, P. \& Hinze, C., 2007. Winery wastewater treatment for vineyard irrigation re-use. Aust. N.Z. Grapegrow. Winem. Annual Technical Issue 2007, 41-45.

Barbera, A.C., Maucieri, C., Cavallaro, V., Ioppolo, A. \& Spagna, G., 2013. Effects of spreading olive mill wastewater on soil properties and crops, a review. Agr. Water Manage. 119, 43-53.

Ben-Asher, J., Tsuyuki, I., Bravdo, B. \& Sagih, M., 2006. Irrigation of grapevines with saline water. I. Leaf area index, stomatal conductance, transpiration and photosynthesis. Agr. Water Manage. 83, 13-21.

Bories, A. \& Sire, Y., 2010. Impacts of winemaking methods on wastewaters and their treatment. S. Afr. J. Enol. Vitic. 31, 38-44.

Buelow, M.C., Steenwerth, K. \& Parikh, S.J., 2015a. The effect of mineralion interactions on soil hydraulic conductivity. Agr. Water Manage. 152, 277-285.

Buelow, M.C., Steenwerth, K., Silva, L.C.R \& Parikh, S.J., 2015b. A California winery wastewater survey: Assessing the salinity challenge for wastewater reuse. Am. J. Enol. Vitic. 31, 38-44.

Campos, C., Oron, G., Salgot, M., Gillerman, L. \& Casals, G., 2000. Attenuation of microorganisms in the soil during drip irrigation with waste stabilization pond effluent. Water Sci. Technol. 42, 387-392.

Chapman, J.A., Correl, R.L. \& Ladd, J.N., 1995. Removal of soluble carbon from winery and distillery wastewaters by application to soil. Aust. J. Grape Wine Res. 1, 39-47.
Conradie, A., 2015. Influence of winemaking practices on the chemical characteristics of winery wastewater and the water usages of wineries. Thesis, Stellenbosch University, Private Bag X1, 7602 Matieland (Stellenbosch), South Africa.

Conradie, A., Sigge, G.O. \& Cloete, T.E., 2014. Influence of winemaking practices on the characteristics of winery wastewater and the water usage of wineries. S. Afr. J. Enol. Vitic. 35, 10-18.

Coppola, A., Santini, A., Botti, P., Vacca, S., Comegna, V. \& Severino, G., 2004. Methodological approach for evaluating the response of soil hydrological behaviour to irrigation with treated municipal wastewater. J. Hydrol. 292, 114-134.

Day, P., Cribb, J., Boland, A., Shanahan, M., Oemcke, D., Kumar, A., Cowey, G., Forsyth, K. \& Burgi, A. 2011. Winery wastewater management and recycling. Operational guidelines. Grape and Wine Research Development Corporation Report, Australia.

Deans, L., 2003. Winery wastewater - Scourge or opportunity? Wine Ind. J. 18, 80-85.

Department of Water Affairs, 2013. Revision of general authorisations in terms of Section 39 of the National Water Act, 1998 (Act No. 36 of 1998), No. 665. Government Gazette No. 36820, 6 September 2013. Department of Water Affairs, Pretoria, South Africa.

Fourie, J.C., Theron, H. \& Ochse, C.H., 2015. Effect of irrigation with diluted winery wastewater on the performance of two cover crops in vineyards. S. Afr. J. Enol. Vitic. 36, 210-222.

Gonçalves, R.A.B., Folegatti, M.V., Gloaguen, T.V., Libardi, P.L., Montes, C.R., Lucas, Y., Dias, C.T.S. \& Melfi, A.J., 2007. Hydraulic conductivity of a soil irrigated with treated sewage effluent. Geoderma 139, 241-248

Hawke, R.M. \& Summers, S.A., 2006. Effects of land application of farm dairy effluent on soil properties: A literature review. N. Z. J. Agric. Res. 49, 307-320.

Howell, C.L. \& Myburgh, P.A., 2014a. Effect of irrigation with augmented winery wastewater on soil chemical status. In: Myburgh, P.A. \& Howell, C.L. (eds). The impact of wastewater irrigation by wineries on soils, crop growth and product quality. WRC Report No. 1881/14. Water Research Commission, Private Bag X103, Gezina, Pretoria, 0031.

Howell, C.L. \& Myburgh, P.A., 2014b. Chapter 10: Effect of irrigation with augmented winery wastewater on the hydraulic conductivity of different soils. In: Myburgh, P.A. \& Howell, C.L. (eds). The impact of wastewater irrigation by wineries on soils, crop growth and product quality. WRC Report No. 1881/14. Water Research Commission. Private Bag X103, Gezina, Pretoria, 0031.

Howell, C.L., Myburgh, P.A. \& Lategan, E., 2014a. Chapter 3: Water quality, irrigation volumes and amount of elements applied via wastewater irrigation. In: Myburgh, P.A. \& Howell, C.L. (eds). The impact of wastewater irrigation by wineries on soils, crop growth and product quality. WRC Report No. 1881/14. Water Research Commission. Private Bag X103, Gezina, Pretoria, 0031.

Howell, C.L., Myburgh, P.A. \& Lategan, E., 2014b. Chapter 7: Effect of irrigation with augmented winery wastewater on grapevine water status, growth, yield and evapotranspiration. In: Myburgh, P.A. \& Howell, C.L. (eds). The impact of wastewater irrigation by wineries on soils, crop growth and product quality. WRC Report No. 1881/14. Water Research Commission. Private Bag X103, Gezina, Pretoria, 0031.

Howell, C.L., Schoeman, C. \& Myburgh, P.A., 2014c. Chapter 8: Effect of irrigation with augmented winery wastewater on juice and wine characteristics with special reference to off-flavours. In: Myburgh, P.A. \& Howell, C.L. (eds). The impact of wastewater irrigation by wineries on soils, crop growth and product quality. WRC Report No. 1881/14. Water Research Commission. Private Bag X103, Gezina, Pretoria, 0031.

Jackson, D.I. \& Lombard, P.B., 1993. Environmental and management practices affecting grape composition and wine quality - A review. Am. J. Enol. Vitic. 44, 409-430. 
Jeison, D., Chamy, R. \& Salgado, E., 2003. Anaerobically treated wastewater in agricultural irrigation as an alternative for post treatment in water-demanding zones. App. Biochem. Biotechn. 109, 197-206.

Kodur, S., 2011. Effects of juice $\mathrm{pH}$ and potassium on juice and wine quality, and regulation of potassium in grapevines through rootstocks (Vitis): A short review. Vitis 50, 1-6.

Kriel, W., 2008. Turning wine into water. Farmer's Weekly, 23 May 2008, 26-27.

Kumar, A., Arienzo, M., Quale, W., Christen, E., Grocke, S., Fattore, A., Doan, H., Gonzago, D., Zandonna, R., Bartrop, K., Smith, L., Correl, R. \& Kookana, R., 2009. Developing a systematic approach to winery wastewater management. Report CSL05/02. Grape and Wine Research Development Corporation/CSIRO Land and Water Science, Adelaide, Australia.

Kumar, A., Rengasamy, P., Smith, L., Doan, H., Gonzago, D., Gregg, A., Lath, S., Oats, D. \& Correl, R., 2014. Sustainable recycled winery water irrigation based on treatment fit for purpose approach. Report CSL1002. Grape and Wine Research Development Corporation/CSIRO Land and Water Science, Adelaide, Australia.

Kumar, A., Saison, C., Grocke, S., Doan, H., Correl, R. \& Kookana, R., 2006. Impact of winery wastewater on ecosystem health - An introductory assessment. Report CSL02/03. Grape and Wine Research Development Corporation/CSIRO Land and Water Science, Adelaide, Australia.

Lado, M. \& Ben-Hur, M., 2009. Treated domestic sewage irrigation effects on soil hydraulic properties in arid and semiarid zones: A review. Soil Till. Res. 106, 152-163.

Lado, M. \& Ben-Hur, M., 2010. Effects of irrigation with different effluents on saturated hydraulic conductivity of arid and semi-arid soils. Soil Sci. Soc. Am. J. 74, 23-32.

Laurenson, S., 2010. The influence of recycled water irrigation on cation dynamics in relation to the structural stability of vineyard soils. Dissertation, University of South Australia, G.P.O. Box 2471, 5001 Adelaide, Australia.

Laurenson, S. \& Houlsbrooke, D., 2012. Review of guidelines for the management of winery wastewater and grape marc. Report prepared for the Marlborough District Council, New Zealand.

Laurenson, S., Bolan, N.S. \& McCarthy, M., 2011. Effects of $\mathrm{K}^{+}$on Na-Ca exchange and the SAR-ESP relationship. Soil Res. 49, 538-54.

Laurenson, S., Bolan, N.S., Smith, E. \& McCarthy, M., 2012. Review: Use of recycled wastewater for irrigating grapevines. Aust. J. Grape Wine Res. $18,1-10$.

Levy, G.J. \& Van der Watt, H., 1990. Effect of exchangeable potassium on the hydraulic conductivity and infiltration rate of some South African soils. Soil Sci. 149, 69-77.

Mahmoud, M., Janssen, M., Haboub, N., Nassour, A. \& Lennartz, B., 2010. The impact of olive mill wastewater application on flow and transport properties in soils. Soil Till. Res. 107, 36-41.

Mathan, K.K., 1994. Studies on the influence of long-term municipal sewage-effluent irrigation on soil physical properties. Biosource Techn. 48, $275-276$.

Matthews, S., 2008. UASB technology adapted to the treatment of winery wastewater. Water Wheel, January/February 2008, 20-22.

Mosse, K.P.M., Lee, J., Leachman, B.T., Parikh, S.J., Cavagnaro, T.R., Patti, A.F. \& Steenwerth, K.L., 2013. Irrigation of an established vineyard with winery cleaning agent solution (simulated winery wastewater): Vine growth, berry quality, and soil chemistry. Agr. Water Manage. 123, 93-102.

Mosse, K.P.M., Patti, A.F., Christen, E.W. \& Cavagnaro, T.R., 2011. Review: Winery wastewater quality and treatment options in Australia. Aust. J. Grape Wine Res. 17, 111-122.
Mosse, K.P.M., Patti, A.F., Smernik, R.J., Christen, E.W. \& Cavagnaro, T.R., 2012. Physicochemical and microbiological effects of long-term and short-term winery wastewater application to soils. J. Hazard. Mater. 201202, 219-228.

Mpelasoka, B, Schachtman, D.P., Treeby, M.T. \& Thomas, M.R., 2003. A review of potassium nutrition in grapevines with special emphasis on berry accumulation. Aust. J. Grape Wine Res. 9, 154-168.

Mulidzi, A.R., 2016. The effect of winery wastewater irrigation on the properties of selected soils from the South African wine region. Dissertation, Stellenbosch University, Private Bag X1, 7602 Matieland (Stellenbosch), South Africa.

Mulidzi, A.R., Clarke, C.E. \& Myburgh, P.A., 2015. Effect of irrigation with diluted winery wastewater on cations and $\mathrm{pH}$ in four differently textured soils. S. Afr. J. Enol. Vitic. 36, 402-412.

Mulidzi, A.R., Clarke, C.E. \& Myburgh, P.A., 2016. Effect of irrigation with diluted winery wastewater on phosphorus in four differently textured soils. S. Afr. J. Enol. Vitic. 37, 79-84.

Mulidzi, R., Laker, G. \& Wooldridge, J., 2009a. Composition of effluents from wineries in the Western and Northern Cape provinces (Part 2): Impacts on soil and the environment. Wynboer Technical Yearbook 2009/10, 62-68.

Mulidzi, R., Laker, G., Wooldridge, J. \& Van Schoor, L., 2009b. Composition of effluents from wineries in the Western and Northern Cape provinces (Part 1): Seasonal variation and differences between wineries. Wynboer Technical Yearbook 2009/10, 58-61.

Myburgh, P.A. \& Howell, C.L., 2014. Assessing the ability of fodder beet (Beta vulgaris L. 'Brigadier') to absorb sodium from a soil irrigated with sodium-enriched water. S. Afr. J. Plant Soil 31, 113-115.

Quale, W.C., Jayawardane, N. \& Arienzo, M., 2010. Impacts of winery wastewater irrigation on soil and groundwater at a winery land application site. Proc. $19^{\text {th }}$ World Congress of Soil Science: Soil solutions for a changing world, August, Brisbane, Australia.

Ryder, R.A., 1995. Aerobic pond treatment of winery wastewater for vineyard irrigation by drip and spray systems in California. Rev. Fr. Oenol. $152,22-24$

Sheridan, C.M., Bauer, F.F., Burton, S. \& Lorenzen, L., 2005. A critical process analysis of wine production to improve cost, quality and environmental performance. Water Sci. Technol. 51, 39-46.

Sheridan, C.M., Glasser, D., Hildebrandt, D., Petersen, J. \& Rohwer, J., 2011. An annual and seasonal characterisation of winery effluent in South Africa. S. Afr. J. Enol. Vitic. 32, 1-8

Smiles, D.E. \& Smith, C.J., 2004. A survey of the cation content of piggery effluents and some consequences of their use to irrigate soils. Aust. J. Soil Res. 46, 67-75.

Sort, X. \& Alcaniz, J.M., 1999. Modification of soil porosity after application of sewage sludge. Soil Till. Res. 49, 337-345.

South African Wine Industry Information and Systems (SAWIS), 2015. South Africa wine industry statistics [Online]: www.wosa.co.za.

South Australian EPA, 2004. Guidelines for wineries and distilleries, South Australian Environmental Protection Agency. Government of South Australia, Adelaide, South Australia.

Sparling, G.P., Barton, L., Duncan, L., McGill, A., Speir, T.W., Schipper, L.A., Arnold, G. \& Van Schaik, A., 2006. Nutrient leaching and changes in soil characteristics of four contrasting soils irrigated with secondary-treated municipal wastewater for four years. Aust. J. Soil Res. 44, 107-116.

Stevens, R.M., Harvey, G. \& Partington, D.L., 2011. Irrigation of grapevines with saline water at different growth stages: Effects on leaf, wood and juice composition. Aust. J. Grape Wine Res. 17, 239-248. 
Stevens, R.M., Harvey, G., Partington, D.L. \& Coombe, B.G., 1999. Irrigation of grapevines with saline water at different growth stages. 1 Effects on soil, vegetative growth and yield. Aust. J. Agric. Res. 50, 343355.

Tarchitzky, J., Golobati, Y., Keren, R. \& Chen, Y., 1999. Wastewater effect on montmorillonite suspensions and hydraulic properties of sandy soils. Soil Sci. Soc. Am. J. 63, 554-560.

Tarchouna, L.G., Merdy, P., Raynaud, M., Pfeifer, H. \& Lucas. Y., 2010. Effects of long-term irrigation with treated wastewater. Part I: Evolution of soil physico-chemical properties. Appl. Geochem. 25, 1703-1710.
Van Schoor, L.H., 2005. Guidelines for the management of wastewater and solid waste at existing wineries. Winetech [Online]: www.winetech.co.za.

Viviani, G. \& Iovino, M., 2004. Wastewater reuse effects on soil hydraulic conductivity. J. Irr. Drain. Eng. Nov/Dec, 476-484.

Vogeler, I., 2009. Effect of long-term wastewater application on physical soil properties. Water Air Soil Poll. 196, 385-392.

Walker, R.R., Blackmore, D.H., Clingeleffer, P.R. \& Iacono, F., 1997. Effect of salinity and Ramsey rootstock on ion concentrations and carbon dioxide assimilation in leaves of drip-irrigated field-grown grapevines (Vitis vinifera L. cv. Sultana). Aust. J. Grape Wine Res. 3, 66-74. 